\title{
High-Revenue Athletics Institutional Policies and Practices Aligned with Key Resources for STEM Career Development
}

\author{
Sheron L. Mark, Ph.D. \\ University of Louisville
}

Abstract: Driven by efforts to support science, technology, engineering, and mathematics (STEM) career development among Black male college athletes, this study sought to explore the ways in which athletics departments within high-revenue National Collegiate Athletic Association Division I universities established institutional policies and practices that aligned with key STEM career development resources. A sample of seven athletics department websites in high-revenue Atlantic Coast Conference institutions were reviewed for evidence of policy and practice alignment with STEM career development. The resources identified from this review included: explicit programming and college athlete experiences for career, personal, and cultural identity development; designated institutional support personnel with the potential to provide personalized social and academic support, including academic advisers, career counselors, and learning specialists; and tutoring and study hall as additional academic support practices. The need for equity and student-centeredness is discussed in regard to the implementation of each of these resources. Also considered in the discussion is the impact of athletics departments that demonstrate leadership, collaboration, and accountability in administering these resources, as compared to university-wide departments of academic and student affairs.

Keywords: science technology engineering and mathematics (STEM), academic success, career development, higher education athletics policy and practice, Black male college athletes

Acknowledgements: The author is grateful to research participants, Ben and Kesh, who participated in an earlier research study, which has led to these subsequent inquiries. The author is additionally grateful to the editorial and review team in providing valuable feedback.

\section{STEM Career Development of Black Male College Athletes}

Researchers have called attention to the overrepresentation of Black males in sports (Cooper et al., 2017; Harper et al., 2013). Meanwhile, they are underrepresented in science, technology, engineering, and mathematics (STEM) degree attainment (National Science Board, 2019). A number of important STEM career development resources that can support college athletes generally, and Black male college athletes particularly, have been identified from a review of existing literature. In the present study, these resources are used to guide an analysis of a number of high-revenue Division I athletic programs to examine how well they may support Black male college athletes' STEM career development.

It is recognized that young Black males, particularly from communities that are constrained 
economically, may strategically use sports to access valuable capital while of school age (Daley, 2012; Davis, 2016; Murty \& Roebuck, 2015; Small, 2016). This access may be in the form of entry into high quality higher education institutions, financial means to afford college, and subsequent high-power, high-earning careers in professional sports, along with business and entertainment; however, this level of success in sports is rare. About four percent of Division I National Collegiate Athletic Association (NCAA) men's basketball athletes attain major professional National Basketball Association (NBA) contracts, along with about one percent of all men's NCAA basketball athletes (NCAA Research, 2018). Beyond the NBA, basketball athletes may attain professional contracts on international teams, on the NBA Development league, and through undrafted opportunities at rates of $19 \%$ for all NCAA men's basketball athletes and $48 \%$ for Division I men's basketball athletes (NCAA Research, 2018). Yet, many more college athletes believe that they can successfully make this transition than data show (NCAA Research, 2016). Importantly still, professional sports careers are relatively short and pose high risks of injuries, declines in performance and competitiveness, and financial hardship, particularly bankruptcy (Coon, 2011; Henry, 2013). It is therefore critically important for Black male college athletes to plan wisely for long-term satisfying careers in, but also beyond, sports. Furthermore, a $21^{\text {st }}$ century STEM-integrated world (President's Council of Advisors on Science and Technology [PCAST], 2010) encourages attention to be placed on Black male college athletes' academic preparation and career participation in STEM disciplines.

Factors counteracting Black male college athletes' opportunities in career development for STEM, as well as in other career fields, include the commercialization and transformation of educational institutions into pipelines to professional sports industries, as opposed to broad educational and career preparation (Gardner \& Wulkow, 2012; Gregory, 2017). Additionally, institutional structures, interpersonal interactions, and societal messages allow for academic exploitation and career development neglect for Black male college athletes (Cooper, 2016; Murty \& Roebuck, 2015). From early in their K-12 education, many Black male college athletes establish the perception of professional sports careers as one of few viable options for economic advancement for themselves and their families. The high levels of profit generation in commercialized college and professional sports (Forbes, 2020; Hruby, 2016; NCAA, 2020) can be particularly attractive to young athletes in comparison to other career fields, as well. Furthermore, relative to sports, Black male career role models are lacking in STEM (Aish et al., 2018; Alston et al., 2017).

Historical and pervasive negative stereotypes about Black male college athletes center on intellectual inferiority, physical prowess and aggressiveness, and academic underachievement (Harrison \& Lawrence, 2004; Sailes, 1993). Such stereotypes may narrow the perceived potential of Black male college athletes to future NBA draft picks and, worse, contribute to the willful academic exploitation and career neglect of these young men. Evidence of this includes: the lower graduation rates, grade point averages, Scholastic Aptitude Test scores, and American College Testing scores of Black male college athletes compared to other racial groups (Harper et al., 2013; Johnson et al., 2013; Snyder, 1996); as well as promoting or condoning a "majoring in eligibility" culture, i.e., doing the academic minimum required to remain qualified to participate in the college sport of interest (Beamon, 2008; Benford, 2007; Comeaux, 2015; Ganim, 2015). Still, some Black male college athletes have shown critical awareness and agency in navigating the institutional and interpersonal structures of the education-sport industry to safeguard their academic advancement 
and future careers (Clark et al., 2015; Cooper \& Cooper, 2015; Cooper \& Hawkins, 2014; Martin et al., 2010).

\section{Critical Race STEM Education and Career Development}

The narrowly emphasized professional sports career pathway, along with Black male college athletes' underrepresentation in STEM careers, has been critiqued from a critical race STEM education and career development perspective (Mark \& Alexander, 2019), undergirded by critical race theory in education (CRT; Ladson-Billings, 1998). CRT is the fundamental notion that racism is a normal, pervasive aspect of life in the United States (U.S.) and serves to maintain the superior social position of Whites over People of Color (Crenshaw et al., 1995). A critical race STEM education and career development perspective recognizes neoliberal capitalistic gains and interest convergence rather than individualism and colorblind meritocracy (Bell, 1992; Hruby, 2016; Ladson-Billings, 1998) regarding Black male college athletes' prospects in sports as compared to STEM. The former may explain Black male college athletes' place in an educationsport industry at the expense of development in other career fields.

In adopting perspectives of individualism and colorblind meritocracy, one may argue that the natural gifts and talents, along with the hard work and dedication of Black male college athletes, have positioned them to compete for and attain NCAA athletic scholarships and subsequent professional sports contracts. Furthermore, this perspective would argue that this pathway is not restricted by race; therefore, the benefits and the costs of this career pathway are equally distributed to all, regardless of race or gender. An emphasis on individual-level control over student success and access to educational resources can also contribute to minimizing the role of institutional policies and practices in education. Critical race theory has long critiqued emphasizing individual-level actions and minimizing the more significant and increasingly invisible role of institution-level structures in maintaining status quo race relations (Bonilla-Silva, 1997). This is worsened when the governing institution for college athletics, i.e., the NCAA, has long established and upheld policies and practices entrenched in colorblind racism (Cooper et al., 2017).

From the perspective of interest convergence, on the other hand, one may argue that the interests of Black communities and other people enduring historical subordination are addressed only when they intersect with the interests of powerful White communities (Bell, 1980). In the education-sport industry, the powerful stakeholders have been predominantly White coaches, university presidents, NCAA leadership, professional league team owners, managers, and those in business and media who reap billion-dollar-level financial rewards from NCAA and professional sports (Forbes, 2020; Hruby, 2016). Such levels of wealth generation are celebrated in capitalistic societies, such as the U.S. Since the 1970s, the assimilation of Black students into historically White institutions via NCAA athletic scholarships furthered these financial interests as opposed to a commitment to social justice (Cooper, 2012; Donnor, 2005; Hawkins, 2010; Sellers, 2000).

Meanwhile, Black male college athletes' educational and career readiness remains underdeveloped in $21^{\text {st }}$ century STEM career fields. It is critically important for Black male college athletes and other student populations who are underrepresented in STEM, including Students of Color and students experiencing economic hardship, to actively participate in and shape STEM career communities. From an institutional perspective, the interests, activities, and outcomes of 
STEM, e.g., healthcare, research and development, education, industrial activity, product development, and community development, are shaped by the people who occupy those STEM career positions, which currently lack racial and ethnic diversity (National Science Board. National Science Foundation, 2020). Equitably advancing the interests of diverse populations and, similarly, protecting populations from harm and exploitation requires more diverse representation within STEM (Brandt, 1978; Haraway, 2013; Roberts, 2013).

In addition to furthering equity and transformation in STEM, Black male college athletes can benefit at an individual level from STEM career participation in terms of economic advancement, job satisfaction, and social recognition (Fayer et al., 2017). Greater financial and social stability can enhance the K-12 and post-secondary educational outcomes of one's own children as socioeconomic status is perniciously tied to student academic achievement (National Science Board, 2016). Furthermore, as STEM career professionals, Black male college athletes can also serve as significantly influential career role models for their own children, as well as to other young people with whom they interact (Aish et al., 2018; Alston et al., 2017; Mark, 2016).

Black male college athletes themselves must understand and reflect on potential academic and career trajectories in sports, STEM, and other fields of interest. In so doing, they will have the capacity to engage in sociopolitical critique of sports, STEM, other career industries, and their own places within these fields. They will furthermore be well-positioned to be self-determined in charting their futures towards dependable, long-term, high quality, and satisfying careers, having weighed the benefits and costs of career participation in sports, STEM, and/or other career fields.

\section{Supporting Success in STEM in Higher Education}

Both academic and social experiences are significant in influencing the success of college athletes in STEM majors (Comeaux et al., 2016). Involvement in "high-impact activities... such as peer study groups, clubs, internships, and structured research projects" (Comeaux et al., 2016, p. 27) support successful progress and degree attainment in STEM. These structured social opportunities provided college athletes assistance and encouragement in mastering coursework, gaining experience in skills necessary for future professional work in STEM fields, and opportunities to socialize and connect with peers in STEM. Social connections and support from mentors was a significant distinguishing factor between two Black male college athletes, Kesh and Ben, whose STEM career development pathways were explored in a critical race case study (Mark \& Alexander, 2019). Specifically, Kesh benefited from the presence of a very strong and consistent long-term mentor. Kesh's mentor helped him maintain his focus on his ultimate STEM career goals through short- and long-term planning. Conversely, Ben commented on the absence of social support in college, specifically his parents, at the time of his decision to change majors and exit the STEM career field.

Athletic participation can cultivate practices and opportunities to help college athletes in STEM establish discipline, balance, and a productive mental health status in both athletics and academics. At the same time, however, the intense athletic schedules of many Division I college athletes can pose barriers to their access and participation in the aforementioned "high-impact activities" (Comeaux et al., 2017). In addition to college athletes' feelings of isolation from their non-athlete peers in STEM, they may also experience isolation from their non-STEM major 
teammates, as their teammates are not involved or may not be able to relate to their coursework and other academic experiences (Comeaux et al., 2016). Additionally, Black male college athletes in STEM majors may struggle to balance the demands of academics, athletics, and socializing with peers and feelings of isolation (Mark \& Alexander, 2019). Under academic duress, some Black male college athletes may elect or perceive pressure to pursue less rigorous academic majors that are promoted as more conducive to the time constraints of an intensive Division I NCAA basketball career; however, this practice has been critiqued in higher education athletics (Comeaux et al., 2017; Fountain \& Finley, 2011).

The resources that support Black male college athletes' STEM career development can be derived from individual and institutional sources. For instance, at an individual level, the college athletes in Comeaux et al.'s (2016) and Mark and Alexander's (2019) studies developed STEM career goals on their own prior to enrolling in college and exhibited personal characteristics and behaviors that supported discipline and determination in academic pursuits. Institutional sources of support for STEM career development would include those academic, career, and social opportunities designed and overseen by university departments, e.g., structured mentorship opportunities, research internship programs, and academic support and enrichment offerings, as opposed to those dependent on college athletes' own initiative and self-organization. Such institutional sources of support are particularly important as these can overcome limitations in individual-level differences in knowledge about and access to resources (Malcom-Piqueux \& Mara Bensimon, 2015). For instance, students, faculty, and college student personnel may be variably knowledgeable about key resources for success in STEM education or similarly be variably provided access to these key resources.

Given the importance of social support, institutional structures can support Black male college athletes in establishing peer networks, as well as mentorship and career role model relationships. Supportive peers and mentors can provide encouragement and challenge Black male college athletes in STEM to establish and follow through with academic and career plans. STEM career professionals can be incredibly educative to young people who are interested but underrepresented in STEM careers by helping them to understand various STEM career fields and professions, the steps necessary to acquire career positions, and the work and lifestyle experiences of those STEM professionals (Mark, 2016). 
Another important critique gained from research on Black male college athletes in STEM was the unfair costs to Black male college athletes' personal educational and career goals (Mark \& Alexander, 2019). Some Black college athletes do not feel sufficiently empowered to challenge the pressure they perceive to change majors and leave the STEM field. This calls for the need for critically conscious and empowered academic/career counseling. Critical consciousness and empowered actions support individuals in critiquing status quo conditions and in engaging in willful action for social change (Ladson-Billings, 1995). Among Black male college athletes, this may include developing the necessary perspectives and language to reflect on and critique their roles, experiences, opportunities, and other outcomes as college athletes from specific racial, gender, and other cultural backgrounds in an education-sport industry and in other professional career fields of interest, such as STEM. In so doing, they may explore the benefits and costs of their participation with respect to both athletics and career development in STEM or any other field. Such counseling would further support college athletes in engaging in discourse and intentional social action through their academic and career decision-making. Furthermore, they should be supported in considering the impact of their participation at both institutional and individual levels. Academic and athletic staff, as well as faculty members, should be similarly informed about and discuss with their college athletes' earlier critiques of the education-sport industry and critical race STEM education as parts of academic advising and career counseling.

A number of academic and social experiences can support or constrain Black male college athletes' STEM career development. Furthermore, institution-level support is critical for ensuring equitable resource access for students in need of support. Therefore, this study sought to examine the ways in which the policies and practices established by high-revenue athletics institutions aligned with key resources that can support Black male college athletes' STEM academic success and career development. The question that prompted the current research investigation was: In what ways have high-revenue athletics institutions established policies and practices that may provide Black male college athletes access to key STEM academic and career development resources?

\section{Methodology}

A sample of seven high-revenue Division I (DI) NCAA universities was systematically selected in order to explore the availability of the aforementioned STEM career development resources. Division I athletics benefit disproportionately from the athletic skills and services provided by Black college athletes (Cooper et al., 2017). Furthermore, as a faculty member in an Atlantic Coast Conference (ACC) institution, I selected the ACC out of the options of high-revenue DI athletic conferences. Next, I selected the highest revenue-earning institutions within that conference, including my home institution. The revenue earned by each of the seven institutions selected in 2017-18 ranged from $\$ 29.7 \mathrm{M}$ to $\$ 31.4 \mathrm{M}$ (Teel, 2019). The selected institutions will be referred to as Institutions $\mathrm{A}, \mathrm{B}, \mathrm{C}, \mathrm{D}, \mathrm{E}, \mathrm{F}$, and $\mathrm{G}(N=7)$.

I began with the athletics department website of each selected institution, as I was seeking evidence of proactive institutional leadership, specifically on the athletics side as opposed to the expected academics and student affairs side of the university. To determine relevant webpages within the athletics website, I reviewed maps overviewing all the areas of the website, i.e., dropdown or pop-up menus with descriptive titles of each page or section of the website. I focused especially on the sections dedicated to academic and "student-athlete" resources and services. On these pages, I sought details about college athlete services, experiences, opportunities, etc., as well 
as programs offered, policies and practices, and collaborations with other departments at each university. Within the academic and "student-athlete" sections for each university's athletics website, the information was read through line by line and coded thematically, starting with the exact language used by the websites, e.g., "learning specialists," "career panel," and "etiquette dinner." Then, as commonalities were identified among websites, the language of the codes was changed to reflect these thematic commonalities, e.g., "social connections with peers," "tutoring services," and "institutional promotion of academic excellence." Coding relied on specific details of resources as opposed to general descriptions in mission statements for departments or "About Us" paragraphs. I sought specific details and definitions of policies, services, experiences, and other resources. For instance, of interest were details about the nature of meetings with athletic staff members or advisers, frequency of meetings, curriculum content of programming provided, and breadth of college athlete experiences in programs.

I was interested in distinguishing between proactive institutional leadership within athletics departments on behalf of their college athletes as opposed to leadership from departments within academics and student affairs units at the university. To accomplish this during data analysis, I sought to identify the unit responsible for implementing and/or overseeing the specific service/resource, e.g., tutoring services, mentorship programs, or career networking panels. If these services were housed within the athletics department and administered by athletics department staff, then institutional leadership within athletics was identified. If academic and "student-athlete" services were advertised on the athletics website(s), but the athletes were directed to units or departments responsible for administering these services to the general university student population, then the leadership was identified as outside of the athletics department(s).

Further guiding the analysis of the athletics departments' websites were the ways in which academic and career counseling were structured. Academic and career counseling are widely established, historical practices in higher education that are, furthermore, expected to be present. From a review of literature earlier in the paper, what is recommended in terms of academic and career counseling are opportunities for critically conscious reflection on one's academic and career trajectories as a college athlete and beyond athletics. Thus, in analyzing the academic and career counseling services advertised as available for college athletes, evidence of opportunities for development of such critical consciousness and empowered decision-making was sought. Evidence in support of this resource provision may potentially include: (a) explicit statements about the goals of the services to support college athletes' self-reflection and autonomous development of satisfactory academic and career pathways; (b) communication and display of data indicating differential representation of college athlete populations, e.g., Black males in specific sports and the economic impact of their participation; (c) summaries of research on commercialized college and professional sports, including ideologically diverse perspectives on the topics involved, e.g. academic integrity, greater participation in the commercial structure of college sports, or athletes' rights and protections (Sack, 2009); and (d) career outlooks in diverse fields, including demographic information of employers and employees in the respective fields.

\section{Findings}

The athletics departments of the various institutions reviewed provided STEM career development resources that included: (a) explicit programming and experiences to support college 
athletes' career, personal, and cultural identity development; (b) institutional personnel assigned to work with college athletes who had the potential to provide personalized social support; and (c) tutoring and study hall. The findings are summarized in Table 1.

\section{Table 1}

Summary of High-Revenue Athletics Institutional Resources Aligned with STEM Career Development

\begin{tabular}{|c|c|c|c|c|c|c|}
\hline Institution & $\begin{array}{l}\text { Critically } \\
\text { Conscious } \\
\text { and } \\
\text { Empowering } \\
\text { Academic } \\
\text { and Career } \\
\text { Counseling }\end{array}$ & $\begin{array}{l}\text { Career } \\
\text { Development } \\
\text { Programming }\end{array}$ & $\begin{array}{l}\text { Personal } \\
\text { Development } \\
\text { Programming }\end{array}$ & $\begin{array}{l}\text { Cultural } \\
\text { Identity } \\
\text { Development } \\
\text { Programming }\end{array}$ & $\begin{array}{l}\text { Institutional } \\
\text { Personnel as } \\
\text { Potential } \\
\text { Social } \\
\text { Support }\end{array}$ & $\begin{array}{l}\text { Tutoring } \\
\text { and Study } \\
\text { Hall }\end{array}$ \\
\hline \multirow[t]{7}{*}{$\mathbf{A}$} & \multirow[t]{7}{*}{-} & $\begin{array}{l}\text { Professional } \\
\text { job market }\end{array}$ & $\begin{array}{l}\text { Diversity and } \\
\text { inclusion }\end{array}$ & $\begin{array}{l}\text { Female college } \\
\text { athletes }\end{array}$ & \multirow{7}{*}{$\begin{array}{l}\text { Available } \\
\text { and well- } \\
\text { defined }\end{array}$} & \multirow{7}{*}{$\begin{array}{l}\text { Available } \\
\text { and well- } \\
\text { defined }\end{array}$} \\
\hline & & $\begin{array}{l}\text { skills } \\
\text { Career fairs \& }\end{array}$ & $\begin{array}{l}\text { Mental health } \\
\text { and wellness }\end{array}$ & $\begin{array}{l}\text { Male college } \\
\text { athletes }\end{array}$ & & \\
\hline & & $\begin{array}{l}\text { information } \\
\text { sessions }\end{array}$ & $\begin{array}{l}\text { Healthy } \\
\text { relationships }\end{array}$ & $\begin{array}{l}\text { International } \\
\text { students }\end{array}$ & & \\
\hline & & $\begin{array}{l}\text { Paid } \\
\text { internships/job } \\
\text { opportunities }\end{array}$ & $\begin{array}{l}\text { Positive } \\
\text { transitions }\end{array}$ & $\begin{array}{l}\text { College } \\
\text { athletes of }\end{array}$ & & \\
\hline & & $\begin{array}{l}\text { Career } \\
\text { advising }\end{array}$ & \multirow[t]{3}{*}{$\begin{array}{l}\text { Personal } \\
\text { branding }\end{array}$} & $\begin{array}{l}\text { Injured college } \\
\text { athletes }\end{array}$ & & \\
\hline & & $\begin{array}{l}\text { Promotion of } \\
\text { graduate } \\
\text { school and } \\
\text { continuing } \\
\text { education }\end{array}$ & & Athlete allies. & & \\
\hline & & $\begin{array}{l}\text { Promotion of } \\
\text { academic } \\
\text { excellence }\end{array}$ & & & & \\
\hline \multirow[t]{3}{*}{ B } & \multirow[t]{3}{*}{-} & Career panels & Leadership & \multirow{3}{*}{$\begin{array}{l}\text { Annual } \\
\text { international } \\
\text { college athletes } \\
\text { luncheon }\end{array}$} & \multirow{3}{*}{$\begin{array}{l}\text { Available, } \\
\text { but details } \\
\text { lacking }\end{array}$} & \multirow{3}{*}{$\begin{array}{l}\text { Available, } \\
\text { but } \\
\text { external to } \\
\text { athletics }\end{array}$} \\
\hline & & $\begin{array}{l}\text { Professional } \\
\text { and peer } \\
\text { networks }\end{array}$ & $\begin{array}{l}\text { College athlete } \\
\text { talent show }\end{array}$ & & & \\
\hline & & $\begin{array}{l}\text { Professional } \\
\text { job market } \\
\text { skills }\end{array}$ & & & & \\
\hline C & - & - & - & - & $\begin{array}{l}\text { Available } \\
\text { and well- } \\
\text { defined }\end{array}$ & $\begin{array}{l}\text { Available } \\
\text { and well- } \\
\text { defined }\end{array}$ \\
\hline
\end{tabular}




\begin{tabular}{|c|c|c|c|c|c|c|}
\hline D & - & $\begin{array}{l}\text { Promotion of } \\
\text { academic } \\
\text { excellence }\end{array}$ & - & - & $\begin{array}{l}\text { Available } \\
\text { and well- } \\
\text { defined }\end{array}$ & $\begin{array}{l}\text { Available } \\
\text { and well- } \\
\text { defined }\end{array}$ \\
\hline \multirow[t]{6}{*}{$\mathbf{E}$} & - & $\begin{array}{l}\text { Professional } \\
\text { job market } \\
\text { skills }\end{array}$ & \multirow{6}{*}{$\begin{array}{l}\text { Stress } \\
\text { management } \\
\text { Leadership }\end{array}$} & \multirow[t]{6}{*}{-} & \multirow[t]{6}{*}{$\begin{array}{l}\text { Available, } \\
\text { but details } \\
\text { lacking }\end{array}$} & \multirow{6}{*}{$\begin{array}{l}\text { Available, } \\
\text { but } \\
\text { external to } \\
\text { athletics }\end{array}$} \\
\hline & & $\begin{array}{l}\text { Career fairs \& } \\
\text { information } \\
\text { sessions }\end{array}$ & & & & \\
\hline & & $\begin{array}{l}\text { Paid } \\
\text { internships/job } \\
\text { opportunities }\end{array}$ & & & & \\
\hline & & $\begin{array}{l}\text { Career } \\
\text { advising }\end{array}$ & & & & \\
\hline & & $\begin{array}{l}\text { Promotion of } \\
\text { graduate } \\
\text { school and } \\
\text { continuing } \\
\text { education }\end{array}$ & & & & \\
\hline & & $\begin{array}{l}\text { Professional } \\
\text { and peer } \\
\text { networks }\end{array}$ & & & & \\
\hline \multirow[t]{2}{*}{$\mathbf{F}$} & \multirow[t]{2}{*}{-} & \multirow{2}{*}{$\begin{array}{l}\text { Promotion of } \\
\text { academic } \\
\text { excellence }\end{array}$} & Leadership & \multirow[t]{2}{*}{-} & \multirow{2}{*}{$\begin{array}{l}\text { Available } \\
\text { and well- } \\
\text { defined }\end{array}$} & \multirow{2}{*}{$\begin{array}{l}\text { Available } \\
\text { and well- } \\
\text { defined }\end{array}$} \\
\hline & & & $\begin{array}{l}\text { Community } \\
\text { service* }\end{array}$ & & & \\
\hline \multirow[t]{2}{*}{ G } & \multirow[t]{2}{*}{-} & \multirow{2}{*}{$\begin{array}{l}\text { Promotion of } \\
\text { graduate } \\
\text { school and } \\
\text { continuing } \\
\text { education }\end{array}$} & - & $\begin{array}{l}\text { College } \\
\text { athletes of } \\
\text { Color }\end{array}$ & \multirow[t]{2}{*}{$\begin{array}{l}\text { Available } \\
\text { and well- } \\
\text { defined }\end{array}$} & \multirow[t]{2}{*}{$\begin{array}{l}\text { Available } \\
\text { and well- } \\
\text { defined }\end{array}$} \\
\hline & & & & $\begin{array}{l}\text { International } \\
\text { college athletes }\end{array}$ & & \\
\hline
\end{tabular}

\section{Career Development Programming}

A significant demonstration of institutional support for college athletes' career development was explicit programming and student experiences developed and/or facilitated by departments of athletics. Institution A stood out in establishing a long-term, structured, four-year career development plan and curriculum for their college athletes, which included professional interviewing skills, etiquette, professional dress, athlete identity transition, financial literacy, ongoing individual advising, career fairs, and "beyond the game" paid internships.

Institution E encouragingly emphasized career exploration and planning from the first year of college athletes' university experiences. Its website advertised individual counseling services, group education programs, career fairs, and networking opportunities, as well as workshops on networking skills, interview preparation, professional social media networks (e.g., LinkedIn), 
resumes, and cover letters. An important characteristic of Institution E's career development plan was transferable skills, which demonstrates to individuals how their experiences and skills in one area can support their success and advancement in another field, such as post-graduate career experiences. Institution E also provided "information sessions" in which companies and organizations interested in hiring college athletes from the institution for internships and/or fulltime positions met with college athletes to present themselves and describe their prospective career positions and desired employees. Many of these employers have proven track records of hiring college athletes from this institution.

Institution A, Institution $\mathrm{E}$, and Institution $\mathrm{G}$ notably promoted continuing education in graduate school as part of their career development programming. Institution A's career center described goals to "promote graduate work and increase postgraduate scholarships and opportunities," Institution E provided networking and information sessions with graduate school programs at its "Career Athlete Networking Forum," and Institution G aimed "to assist college athletes during their collegiate careers in preparation for employment or admission into graduate school upon graduation."

Other universities, such as Institution B, provided structured career development programming, but these were less expansive compared to those advertised by Institution A and Institution E. Specifically, their programming included a career panel, as well as an annual "Etiquette Dinner" during which college athletes learn about fine dining and formal dinners and are served a 3-course meal. The dinner also included a mini professional fashion show and networking opportunities.

Noteworthy, as well, is the promotion and celebration of academic excellence among college athletes. Institution $\mathrm{A}$ and Institution $\mathrm{F}$, for instance, have accomplished this through annual college athlete awards ceremonies, while Institution D designed and promoted graphic signage on its athletics website that summarized the academic accomplishments of its college athletes, e.g., average GPA and number of academic honor roll college athletes.

Importantly, the programs and college athlete experiences described above were explicitly detailed and clearly promoted on the athletics websites of the sample institutions. Athletics websites are thoroughly explored by prospective and current college athletes and are main sources of information for college athletes and families. Therefore, it is significant that these career development resources are made highly visible. This is not always the case, as such explicit career development programming plans and details were not successfully located for Institution $\mathrm{C}$ and $\mathrm{F}$.

There was evidence of institutional structures and practices that can support college athletes in accessing/establishing social support systems, including mentors and career role models. For instance, Institution E's career development programs and alumni database aimed to help college athletes develop and maintain social connections within various career networks. Similarly, Institution B's career panel provided opportunities for current college athletes to learn from and meet with "former . . college athletes involved in a wide range of careers surrounding Sports, Sports Management, Business, STEM, and Entrepreneurship." Both of these opportunities may support college athletes in identifying and establishing personal/one-on-one mentoring/role 
model relationships with career professionals who may provide encouragement, motivation, specific career knowledge and insight, or other important resources.

\section{Personal Development Programming}

Along with earlier career development programming, Institution A, Institution E, and Institution B established and facilitated similarly structured programs that target college athletes' personal development that impact them as both individuals and members of wider and more diverse communities. Institution A, for instance, created programming on "topics such as diversity and inclusion, mental health and wellness, healthy relationships, positive transitions, and personal branding" and Institution E addressed stress management.

A number of institutions focused these programs on developing their college athletes' leadership skills. Institution B launched a leadership academy for its college athletes, which "will focus on accountability, building confidence, personal growth, as well as collective and individual leadership." Institution E established a series of leadership programs for college athletes at various years into their university careers, including team captains and those in other leadership positions. For Institution F, there was evidence in the form of extensive press releases and media coverage of leadership and community service work accomplished by college athletes; however, from a perspective of the institution supporting college athletes in accessing these experiences as a valuable career development resource, there was a lack of clear information about how a college athlete would participate in such services or structured programming to cultivate targeted skills/knowledge.

These personal development program curricula also facilitated opportunities to establish personal connections with potential career mentors and role models, especially when involved in community service opportunities. These experiences particularly facilitated opportunities for college athletes to foster social connections with other college athletes and other students across the wider university community. Institution B, for instance, hosts an annual talent show to provide "fun, interactive" opportunities for college athletes to showcase their wider interests and skills in a university-wide event.

\section{Cultural Identity Development Programming}

Two universities, Institution $A$ and Institution $\mathrm{G}$, distinguished themselves in creating programs and support groups/networks for college athletes based on the diversity of cultures represented within athletics. Participation in or reliance on these groups may help college athletes meet needs or access resources based on various aspects of their identities or cultural backgrounds. Institution A, for instance, established support groups for female college athletes, male college athletes, international students, college athletes of Color, injured college athletes, and athlete allies. 
Institution $\mathrm{G}$ created two specialized groups to help meet the needs of college athletes of Color and international college athletes. Participating college athletes benefit from programming and opportunities to become involved in campus-wide and community experiences. Institution B has responded to its diverse international college athletes through its programming, but less so than Institution $A$ and Institution $G$. Institution B hosts an annual luncheon for new and returning international college athletes where attendees learn valuable information about the logistics of attending university in a foreign country from the university-wide Office of International Students.

All of the cultural identity development programming and support group/network opportunities aimed to facilitate participating college athletes in fostering social connections with other college athletes who share these similar cultural backgrounds and experiences.

\section{Institutional Personnel as Potential Social Support}

The various athletics institutions have designated personnel to provide key academic support and career development services to college athletes. The personnel and support services described next are not guaranteed to translate into consequential social support for college athletes' career development, but are indicators of potential that are possible, at least, based on the institutional systems established thus far.

At each of the institutions, learning specialists, academic advisers, and career counselors are available or assigned to work with college athletes. These key personnel were identified as located either in-house within the athletics departments themselves or accessible based on collaborations between departments of athletics and university-wide academic affairs. Some institutions communicated the presence and responsibilities of these individuals more explicitly than others. In particular, Institution A, Institution $\mathrm{C}$, and Institution $\mathrm{G}$ did so for academic advisers and career counselors. In addition to these three institutions, Institution F and Institution D clearly identified the availability and responsibilities of learning specialists; however, all of the institutions reviewed make learning specialists, academic advisers, and career counselors available to their college athletes. Others' resource information was less explicit, e.g., accessible via links to additional websites or university-wide academic affairs departments external to athletics departments. Institution B, for instance, identified that academic and career advising is available, but details of the practices and expectations were not located.

Learning specialists work with college athletes one-on-one and/or in groups to develop and pursue individualized learning plans to address academics and skills in need of development. For instance, at Institution C, college athletes meet with learning specialists "several times a week" to create individualized academic plans for athletes with academic challenges, learning disabilities, or ADD/ADHD. The learning specialists also work with college athletes to develop strategies and skills to aid them in moving forward successfully. At Institution F, such strategies and skills included critical thinking, note-taking, test-taking, studying, time management, and organization. Academic mentors and counselors monitor college athletes' academic progress, class attendance, and other indicators of success or concern, as was the case at Institution G. They also potentially provide encouragement, coaching, and social support. 


\section{Tutoring and Study Hall}

Tutoring and study hall are traditional academic practices upheld within athletics departments, whereby tutoring services are made available, study hall policies are established, including GPA requirements and minimum hours for attendance, and dedicated space for college athletes to study, complete coursework, and access computer technology in academic resource centers are created. These serve to support the academic needs and progress of college athletes, as well as to help maintain their academic eligibility to compete in athletics competitions. As in earlier discussion, Institution C, Institution A, Institution F, Institution G, and Institution D detailed their practices and/or expectations regarding tutoring and study hall on their athletics websites, while others' resource information was less explicit. Such content included less accessible links to additional websites or university-wide academic affairs departments, which were external to athletics departments.

Practices and expectations included tutors who were available across a wide range of subject areas, including math, history, science, writing, and foreign languages, as well as lowerand upper-level courses. Institution A provides tutoring for all courses. Individual, small group, and drop-in tutoring options were also available. Some institutions, such as Institution C, Institution $\mathrm{A}$, and Institution $\mathrm{G}$ further promoted the high quality of their tutors as being certified by the College Reading and Learning Association (CRLA), a rare nation-wide accomplishment.

Study hall may be supervised, and the requirements are determined by the academic counselors and athletic coaches, as is the case at Institution C and Institution F. At Institution A, notes about the nature of each tutoring session are reviewed daily by academic advisers and the tutor coordinator. Similarly, at Institution D, tutors communicate with the tutor coordinator, academic coordinators, and study hall monitors by providing reports for assigned sessions. Tutors may also be trained in NCAA rules. Institution A and Institution $G$ ensure such training. Given the widespread tradition of tutoring and study hall, it was noteworthy to review Institution G's description of study hall practice as an "objective based study hall" in which college athletes work to complete weekly objectives in a structured environment with specific stipulations, e.g., the number of study hall hours and upper-classmen requirements.

\section{Critically Conscious and Empowering Academic and Career Counseling}

Based on the online descriptions of the academic and career counseling goals and services, as well as related content displayed online, none of the institutions communicated an explicit commitment to providing academic and career counseling that may be described as critically conscious and empowering to college athletes. The descriptions of career development and cultural identity development programming were not framed in ways that indicated clear support to engage athletes in problematizing professional careers in and beyond sport from individual and institutional perspectives. Similarly, there was no evidence in support of aiding college athletes in problematizing commercialized college sports in ways similar to faculty researchers on the topic. This would be an important step in supporting college athletes in the following three areas: critical consciousness and empowered social action for change in support of academic integrity, greater participation and decision-making in the commercial structure of college sports, and athletes' rights and protections. 


\section{Discussion}

Coaches and athletics departments have power in influencing college admissions and financial aid decisions for some students as college athletes (Sack, 2009). This encourages corresponding leadership and action from within athletics departments in establishing the necessary academic and career development resources for these students. To seek evidence of this institutional leadership in athletics, websites for the seven highest revenue-earning ACC institutions were reviewed for policies and practices that aligned with key resources that can support Black male college athletes' STEM career development. Institutional resources identified from this analysis included: (a) career, personal, and cultural identity programming and student experiences; (b) designated institutional personnel; and (c) tutoring and study hall support services. There was a lack of evidence of critically conscious and empowering academic and career counseling.

Critically conscious and empowering academic and career counseling at the institutional level is important in disrupting status quo NCAA policies and practices undergirded by colorblind racism (Cooper et al., 2017). University athletics departments that similarly fail to center race, to acknowledge specific racial and cultural differences among student populations across sports, or to establish and promote race-conscious policies and practices similarly engage in colorblind racist educational practices relevant to STEM, as well as other academic/career fields. None of the mission statements and goals, descriptions of college athlete programming and events, data on college athletes and athletics, etc., were framed in ways that were critically race-conscious. Neither were these resources framed as intending to support college athletes in self-reflection and sociopolitical critique of potential career pathways and/or commercialized college sports, especially in regard to their racial, gender, and cultural identities. An acknowledged limitation is that, while evidence is possible at an institutional level, individual college athletes' development of critical consciousness and empowered action may be more effectively illuminated through interviews and focus groups. Given the rise in social media communication, this presents another potential source of evidence to explore athletes' discourse on college sports and other relevant topics from a critical race consciousness perspective.

At present, evidence for institutional resources that create the space for college athlete critical self-reflection and career decision-making may be, at best, indicated by the provision of cultural identity development programming. These resources have acknowledged the intersectional identities of college athletes in terms of race, gender, nationality, ability, sexuality, and other aspects of culture and have created opportunities for college athletes to cultivate social connections with others who are culturally similar, as well as different, from themselves. This acknowledgement of intersectionality is foundational to a critical race-conscious approach to education and human development (Delgado \& Stefancic, 2017) and is an encouraging resource. In these spaces, college athletes may consider their academic, athletic, and career trajectories from such intersectional lenses and, hopefully, explore and question ways that these trajectories differ or overlap compared to their peers based on cultural background. Hopefully such exploration and questioning extend beyond consideration of college athletes as individuals to consider group-level and institutional patterns, i.e., disproportional representation of racial and/or gender groups in particular sports, differences in academic and career performances, and outcomes among college athletes in different cultural groups and/or sports. 
K-12 academic "achievement gaps" are symptomatic of historical educational debt to Black communities and communities that are constrained economically (Ladson-Billings, 2006). Furthermore, institutional inaction to disrupt these patterns in academic and career disparities are in alignment with colorblind racist policies and practices (DeCuir \& Dixson, 2004). As such, if universities admit Black male athletes who are academically underprepared for college primarily on the basis of their athletic talents and subsequent services to the institution, but then minimally support their academic and career development while enrolled, then these institutions are condoning systemic racism in K-12 and higher education, along with other societal disparities. Simply reducing or eliminating the pathways by which athletes (who are academically underprepared for college) gain access to higher education by special admissions is not unanimously advised, as this can exacerbate educational and social inequities (Cooper et al., 2017). Rather, it is argued that universities can be required to show evidence of academic progress that compellingly demonstrates strides in overcoming historical systemic inequities. For instance, individual college athletes could show evidence of meaningful gains in academic skills and content, along with independence and leadership in their coursework and academic/career decision-making (Cooper et al., 2017). Cooper et al. (2017) additionally suggest that institutional accountability should be tied to financial penalties and scholarship opportunities

The academic advisers, career counselors, and learning specialists employed by all of the institutions reviewed in this study have critical roles to play in disrupting these patterns in systemic K-12 and higher education inequities, as well as pernicious aspects of high-revenue Division I college athletics culture that negatively position Black male college athletes (Beamon, 2008; Benford, 2007; Harrison \& Lawrence, 2004; Sailes, 1993). These individuals can support compelling academic progress among Black male athletes who enter college academically underprepared. Academic standards and expectations for these athletes must be high and educational experiences enhanced (Comeaux, 2015), whereby these advisers and counselors provide equitable, student-centered support that prioritizes the academic and career interests of college athletes over institutional athletics. These institutional personnel can provide both instrumental and social support to college athletes, especially in pursuing STEM majors (Mark, 2016). Instrumental support can include providing college athletes with individualized academic plans, including any necessary compensatory resources or skills development. Specific information provided should help college athletes make well-informed decisions about academic programs/career plans and identify strategies to adopt to successfully complete coursework. Social support can include coaching and encouraging college athletes, facilitating college athletes' access to career role models and career-related experiences, and being generally positive influences in the lives of college athletes.

The services provided by academic advisers, career counselors, and learning specialists can be further enhanced by collaborative relationships with university faculty, as well as researchers in state and local institutions. It has been argued that such collaborations can work to develop systematic data-driven research on educational interventions, including culturally relevant programming, to increase the academic preparedness of college athletes, especially those underserved on the basis of race and income (Cooper et al., 2017). Even more, the NCAA can mobilize its financial power and "create more research grants ... and collaborate with sponsoring organizations to increase support to [K-12] school districts that historically produce college athletes who are underprepared to enhance academic readiness" (Cooper et al., 2017, p. 219). 
Additionally, it would be important for athletics departments to consider the diversity among their academic advisers, career counselors, learning specialists, and tutors in comparison to the diversity of their college athlete population, especially those who most heavily utilize these academic and career services. K-12 Students of Color, especially those with low socioeconomic status, benefit from opportunities to learn from and engage with Teachers of Color (Ahmad \& Boser, 2014; Carter Andrews et al., 2019). Similarly, college athletes of Color and/or students from communities constrained economically may benefit from opportunities to engage with and learn from academic and career personnel who are culturally similar to them or who share similar experiences.

Some of the athletics departments reviewed were already working in collaboration with other university departments; however, the nature of the collaborations that were promoted tended to be those between athletics departments and university-wide academic and student affairs departments for the purposes of academic and career counseling and tutoring services, e.g., university career services. These collaborations facilitate accessing and capitalizing on the expertise of faculty and staff in academic and college student development affairs throughout the university, in addition to the expertise of athletics staff. These collaborations may also support college athletes' awareness of and participation in broader university activities and facilities.

Beyond collaborations, some athletics departments demonstrated leadership in designing and facilitating their own specialized career development resources for college athletes, including programming, academic and career counselors, learning specialists, and tutors. These resources were structured in-house as opposed to university-wide, i.e., in academic support centers located within the athletes' main athletics facilities where they spend significant time training and socializing. Locating academic and career development resources in-house may demonstrate greater investment and attention to college athletes' academic and career development by athletics staff themselves. The in-house development of these resources are, at least in part, reflective of a capitalist belief held by many. Specifically, many argue that if the business of college sports is competitive, then the profits generated can support the academic needs of athletes, for instance, by financing academic support centers, technology, and staff (Sack, 2009). Potentially, this symbol of in-house academic resources can communicate messages of accountability and academic expectations to college athletes from coaches and other athletics staff, especially since the coaches and staff can better witness, track, and ascertain data about college athletes' utilization of these services. While an in-house model may symbolize athletics leadership and accountability over college athletes' academic and career development, the resources and services provided may still be best derived from and implemented based on systematic data-driven research and collaboration with diverse faculty researchers and college student personnel.

With the growth of athletics revenue at the NCAA and university levels, many Division I athletics programs established or enhanced their college athlete academic support centers and available staff (Wolverton, 2008). Thus, it was expected that each of the high-revenue Division I athletics programs reviewed would have a dedicated academic support center with high quality technology and support staff. Of particular interest in this study was how the academic and career development resources within these centers were defined and organized, along with the involvement and/or leadership of athletics departments in the provision of the resources. The NCAA states that they support college athletes in their member institutions/universities "by providing state-of-the-art technology, tutoring and access to academic advisers" (NCAA, n.d.). 
The position is clear that the NCAA and its member institutions emphasize and are willing to invest highly in academic centers, staff, and support services. Less clear, however, is the NCAA's position on how these services and related programming should be structured. Namely, options include in-house for athletics department leadership and oversight, collaborative partnership between athletics and university-wide academic departments, or external housing in the same university-wide academic and career development counseling centers for non-athletes. Universitylevel autonomy in determining how they wish to structure, house, and deliver these academic and career support services may be well-advised, as each institutional context differs and each institution may desire the opportunity to explore and develop structures and programming best suited for their goals and contexts. In one proactive approach, however, the NCAA has provided grant funding to support eligible Division I institutions with demonstrated need in improving academic and graduation outcomes for college athletes, including establishing and expanding programming and increasing academic support staff and technology (NCAA, 2014). Several of the institutions benefitting from these grants, none of which were included in this current study, enhanced their tutoring, learning specialist, and mentoring services that were administered via inhouse models.

In contrast to collaborative and in-house models, some of the athletics departments referred college athletes to external university-wide academic affairs resources, as opposed to showing evidence of collaboration or leadership. They did this, for instance, by providing links on their athletics websites to direct their athletes to the websites of university-wide departments detailing resources for all students. While this referral acknowledges the expertise among those in academic affairs, collaboration and leadership can communicate to college athletes and families that athletics staff are invested in the holistic development of their athletes and are driven to grow academic and career development expertise within their athletic departments.

Advocates for increasing the academic integrity of college sports have argued for an organizational structure in which academic support services for college athletes are housed, overseen, and delivered in the same ways for both athletes and non-athletes in order to support greater faculty and academic staff involvement and oversight (Sack, 2009). Thus, athletics departments referring college athletes to university-wide academic centers and departments is consistent with this recommendation. At the same time, for college athletes who are unaware, uninterested, constrained by practice and competition schedules, or at risk of enculturation where they prioritize athletics over academics (Mark \& Alexander, 2019), referring college athletes to resources external to their main athletic departments may potentially reduce the accessibility and utilization of these resources, further narrowing their focus on athletics. Overall, however, both inhouse academic support services and academic support services for all college students, including athletes, in the same facilities are argued as potentially more effective than referrals to external departments without sufficient details or without demonstrated athletics department investment or prioritization.

Some of the institutions reviewed provided enhanced educational and career development opportunities by promoting graduate school, as well as potential funding opportunities for postgraduate experiences. While this is encouraging, as college athletes have the opportunity to learn about and consider academic and career experiences beyond NCAA sports, caution may be warranted in light of earlier critiques of colorblind racism, economic exploitation, and academic 
neglect. Of particular concern here is the practice of redshirting, which can extend the number of years within which college athletes have to complete four years of competition. Redshirting can provide college athletes five years, instead of four, to complete their undergraduate degree, which may increase the chances of academic success (Allen et al., 2008; Wilkes, 2014). Some academically high-achieving college athletes also pursue and/or complete graduate study during this extended time (Haslerig, 2017). The concern is largely for college athletes, especially Black male college athletes in the high-revenue DI sports of basketball and football, for whom redshirting may be used to extend their availability to provide athletic service to the institution. This can be achieved by using the freshman year as a development stage for more impactful competition in subsequent years, as opposed to genuine opportunities to support academic success or where redshirting does not increase the time taken for one's undergraduate degree (Rubin, 2016). It is hoped that graduate school enrollment is not an alternative form of this latter possibility, not promoted as limited to the college athletes' present institution of enrollment only, and instead truly supports college athletes in their academic and career development, along with their athletic careers (Martin, 2008). This concern also encourages exploration into the graduation/attrition rates of graduate-level college athletes across sports and from various cultural backgrounds. Along with promoting advanced graduate study, a number of institutions promoted college athlete academic excellence. This is noteworthy, as strong academic self-concepts undergird the establishment of career interests and choice actions towards those careers (Luzzo et al., 1999).

\section{Limitations and Future Research}

An important limitation that is acknowledged in conducting this research was that the institutional resources that have been identified can only be recognized in terms of their potential and not in terms of their measured impact on Black male college athletes. The study is limited to the level of potential, as the provision of resources to college athletes is not solely dependent on institutional leadership in establishing policies and practices; rather, institutional activity and individual agency work together (Baez, 2000; Lavoie, 2014). Consequently, while institutional leadership is necessary to overcome systemic inequities (Malcom-Piqueux \& Mara Bensimon, 2015), the fidelity and efficacy of policy and practice implementation can be limited by individuallevel action to support or undermine the intent. These individual-level actions can, furthermore, be intentional or unintentional, as well as conscious or subconscious.

Another limitation of the study is that, while STEM career development is of interest, the academic and career development resources identified are intended for the general college athlete population and not specifically for those in STEM. Further research will need to examine how Black male college athletes already enrolled as STEM majors or interested in STEM majors experience these resources. Relatedly, the services, experiences, policies, etc., described on the websites reviewed have yet to be investigated in practice. Thus, the efficacy of institutional policy and practice must be further explored through subsequent research with the intended student population(s), in this case, Black male college athletes. The research should include athletes who have opportunities to voice their perspectives and experiences, as well as largescale and long-term analyses of college athlete success and outcomes.

\section{Conclusions}


This study was motivated by a desire to disrupt academic neglect and economic exploitation of Black male college athletes in an education-sport industry that spans K-16 education, college sports, and professional sports. While the benefits and power of sports for Black males and others are acknowledged, this study argues for Black males to be holistically educated and developed, both in terms of academics and critical consciousness, such that they are wellinformed and self-determined in their decision-making in and beyond sports. Furthermore, while they may have athletic gifts or possess the discipline and drive to develop the skills necessary to succeed in sports, their underrepresentation and lack of development in fields beyond sports, especially STEM, is of concern. Of special emphasis are the individual benefits they can accrue from STEM engagement and their potential in transforming the structure of the STEM field.

A lack of equitable academic and career development in STEM for all students is problematic. This problem is worsened when college athletes' career interests and exploration are reduced and/or truncated in the interest of high-revenue sports, coupled with the athletes' acknowledged limitations in informed academic and career decision-making and perceived institutional pressure (Mark \& Alexander, 2019). These critiques are consistent with earlier calls for reforms in college sports that advocate for athletes to successfully pursue the academic major of their choice (Sack, 2009). As such, the analysis conducted in this study sought to explore present-day policies and practices of high-revenue university athletics institutions in support of such reforms. It is acknowledged, however, that there is a diversity of ideological perspectives on issues of college athletes' academic and career development, college sports, commercialized education-sport industries, and other related topics. Such ideological diversity is needed to best understand and reform the challenges associated with these social issues (Sack, 2009).

From an analysis of the seven highest earning ACC institutions in 2017-2018, institutional STEM career development resources included: (a) explicit programming and college athlete experiences for career, personal, and cultural identity development; (b) designated institutional support personnel, including academic advisers, career counselors, and learning specialists, with the potential to provide personalized social support and academic support; and (c) tutoring and study hall as additional academic support practices. All of these resources should be equity-driven and student-centered and are, furthermore, considered as potentially effective, rather than guaranteed, due to the tensions between institutional structures and individual agency in disrupting systemic oppression (Lavoie, 2014). Athletics departments can demonstrate leadership, engaged collaboration, and accountability in administering these resources. Future research may explore institutional resources that support critically conscious and empowering career outlooks among college athletes, as well as explore the experiences and trajectories of graduate college athletes in high-revenue sports. 


\section{References}

Ahmad, F. Z., \& Boser, U. (2014). America's leaky pipeline for teachers of color: Getting more teachers of color into the classroom. Center for American Progress.

https://www.americanprogress.org/issues/race/report/2014/05/04/88960/americas-leakypipeline-for-teachers-of-color

Aish, N., Asare, P., \& Miskioğlu, E. E. (2018, March 10). People like me: Providing relatable and realistic role models for underrepresented minorities in STEM to increase their motivation and likelihood of success. [Conference session]. IEEE Integrated STEM Education Conference, Princeton, NJ, United States.

Allen, J., Robbins, S. B., Casillas, A., \& Oh, I.-S. (2008). Third-year college retention and transfer: Effects of academic performance, motivation, and social connectedness. Research in Higher Education, 49(7), 647-664. https://doi.org/10.1007/s11162-0089098-3

Alston, G. D., Guy, B. S., \& Campbell, C. D. (2017). Ready for the professoriate? The influence of mentoring on career development for Black male graduate students in STEM. Journal of African American Males in Education, 8(1), 45-66.

https://jaamejournal.scholasticahq.com/article/18485-ready-for-the-professoriate-theinfluence-of-mentoring-on-career-development-for-black-male-graduate-students-in-stem

Baez, B. (2000). Agency, structure, and power: An inquiry into racism and resistance for education. Studies in Philosophy and Education, 19(4), 329-348. https://doi.org/10.1023/A:1005241732091

Beamon, K. K. (2008). "Used goods": Former African American college student-athletes' perception of exploitation by division I universities. The Journal of Negro Education, 77(4), 352-364. http://www.jstor.org/stable/25608704

Bell, D. (1980). Brown v. board of education and the interest-convergence dilemma. Harvard Law Review, 93(3), 518-533. https://doi.org/10.2307/1340546

Bell, D. (1992). Racial realism. Connecticut Law Review, 24(2), 363-379. 
Benford, R. D. (2007). The college sports reform movement: Reframing the "edutainment" industry. Sociological Quarterly, 48(1), 1-28. https://doi.org/10.1111/j.1533$\underline{8525.2007 .00068 . \mathrm{x}}$

Bonilla-Silva, E. (1997). Rethinking racism: Toward a structural interpretation. American Sociological Review, 62(3), 465-480. https://doi.org/10.2307/2657316

Brandt, A. M. (1978). Racism and research: The case of the Tuskegee syphilis study. The Hastings Center Report, 8(6), 21-29. https://doi.org/10.2307/3561468

Carter Andrews, D. J., Castro, E., Cho, C. L., Petchauer, E., Richmond, G., \& Floden, R. (2019). Changing the narrative on diversifying the teaching workforce: A look at historical and contemporary factors that inform recruitment and retention of teachers of color. Journal of Teacher Education, 70(1), 6-12. https://doi.org/10.1177/0022487118812418

Clark, L., Harrison, L., \& Bimper, A. Y. (2015). Generations: Academic and athletic integration of a southern PWI basketball program. Research Quarterly for Exercise and Sport, 86(3), 281-291. https://doi.org/10.1080/02701367.2015.1009529

Comeaux, E. (2015). Innovative research into practice in support centers for college athletes: Implications for the academic progress rate initiative. Journal of College Student Development, 56(3), 274.

Comeaux, E., Bachman, T., Burton, R. M., \& Aliyeva, A. (2016). Undergraduate experiences of division I athlete science, technology, engineering, and mathematics (STEM) graduates. Journal of Science Education and Technology, 26(1), 24-32. https://doi.org/10.1007/s10956-016-9648-y

Comeaux, E., Griffin, W., Bachman, P., \& Porter, J. (2017). NCAA division I athlete STEM graduates. Journal of Intercollegiate Sport, 10(1), 44-66.

Coon, L. (2011, November 13). Lockout: What will the players do next? ESPN. http://www.espn.com/nba/story//page/nextforplayers-111114/nba-players-donext?redirected=true 
Cooper, J. N. (2012). Personal troubles and public issues: A sociological imagination of Black athletes' experiences at predominantly White institutions in the United States. Sociology Mind, 2(3), 11, Article 20935. https://doi.org/10.4236/sm.2012.23035

Cooper, J. N. (2016). Excellence beyond athletics: Best practices for enhancing Black male student athletes' educational experiences and outcomes. Equity \& Excellence in Education, 49(3), 267-283. https://doi.org/10.1080/10665684.2016.1194097

Cooper, J. N., \& Cooper, J. E. (2015). “I'm running so you can be happy and I can keep my scholarship": A comparative study of Black male college athletes' experiences with role conflict. Journal of Intercollegiate Sport, 8(2), 131-152. https://doi.org/10.1123/jis.2014$\underline{0120}$

Cooper, J. N., \& Hawkins, B. (2014). The transfer effect: A critical race theory examination of Black male transfer student athletes' experiences. Journal of Intercollegiate Sport, 7(1), 80-104. https://doi.org/10.1123/jis.2013-0033

Cooper, J. N., Nwadike, A., \& Macaulay, C. (2017). A critical race theory analysis of big-time college sports: Implications for culturally responsive and race-conscious sport leadership. Journal of Issues in Intercollegiate Athletics, 10, 204-233. http://csri-jiia.org/wpcontent/uploads/2017/12/RA_2017_11.pdf

Crenshaw, K., Gotanda, N., Peller, G., \& Thomas, K. (Eds.). (1995). Critical race theory: The key writings that formed the movement. New Press.

Daley, J. (2012). Why more pro athletes are scoring franchises after sports fame. Entrepreneur. https://www.entrepreneur.com/article/222671

Davis, S. (2016). The NBA sent players to Google, Facebook, and more to help answer one of the biggest questions of their careers - life after basketball. Business Insider. http://www.businessinsider.com/nba-players-at-google-facebook-careers-after-basketball$\underline{2016-10}$

DeCuir, J. T., \& Dixson, A. D. (2004). "So when it comes out, they aren't that surprised that it is there": Using critical race theory as a tool of analysis of race and racism in education. Educational Researcher, 33(5), 26-31. https://doi.org/10.3102/0013189X033005026 
Delgado, R., \& Stefancic, J. (2017). Critical race theory: An introduction (3rd. ed.). New York University Press.

Donnor, J. K. (2005). Towards an interest-convergence in the education of African-American football student athletes in major college sports. Race Ethnicity and Education, 8(1), 4567. https://doi.org/10.1080/1361332052000340999

Fayer, S., Lacey, A., \& Watson, A. (2017). STEM occupations: Past, present, and future. U.S. Bureau of Labor Statistics. https://www.bls.gov/spotlight/2017/science-technologyengineering-and-mathematics-stem-occupations-past-present-and-future/pdf/sciencetechnology-engineering-and-mathematics-stem-occupations-past-present-and-future.pdf

Forbes. (2020, February 11). The business of basketball: Forbes Releases 22nd annual NBA team valuations. https://www.forbes.com/sites/forbespr/2020/02/11/the-business-ofbasketball-forbes-releases-22nd-annual-nba-team-valuations/\#3b698c6f75ff

Fountain, J. J., \& Finley, P. S. (2011). Academic clustering: A longitudinal analysis of a Division I football program. Journal of Issues in Intercollegiate Athletics, 4, 24-41.

Ganim, S. (2015). Lawsuit claims UNC and NCAA broke promises in 'spectacular fashion.' CNN. http://www.cnn.com/2015/01/22/us/unc-paper-classes-lawsuit/

Gardner, R. B., \& Wulkow, R. (2012). Basketball factories miss mission of high school game. High School Today. https://www.nfhs.org/media/155500/High_School_Today_January_2012.pdf

Gregory, S. (2017, September 4). Kid sports, inc.: How your child's rec league turned into a \$15 billion industry. Time, 42 - 51. http://time.com/4913687/how-kids-sports-became-15billion-industry/

Haraway, D. (2013). Situated knowledges: The science question in feminism and the privilege of partial perspective. In M. Wyer, M. Barbercheck, D. Cookmeyer, H. Ozturk, \& M. Wayne (Eds.), Women, science, and technology: A reader in feminist science studies (pp. 318 - 333). Routledge. 
Harper, S. R., Williams Jr, C. D., \& Blackman, H. W. (2013). Black male student-athletes and racial inequities in NCAA Division I college sports. University of Pennsulvania, Center for the Study of Race \& Equity in Education.

Harrison, K. C., \& Lawrence, S. M. (2004). College students' perceptions, myths, and stereotypes about African American athleticism: A qualitative investigation. Sport, Education and Society, 9(1), 33-52. https://doi.org/10.1080/1357332042000175809

Haslerig, S. (2017). Who or what are graduate(d) student-athletes?: Defining a misunderstood sub-population. Journal of Higher Education Athletics \& Innovation, 2, 110-122.

Hawkins, B. (2010). The new plantation: Black athletes, college sports, and predominantly White NCAA institutions. Springer.

Henry, R. (2013). Business, bankruptcy, and beliefs: The financial demise of NBA stars. Institute for the Study of Labor. http://ftp.iza.org/dp7238.pdf

Hruby, P. (2016). Four years a student-athlete: The racial injustice of big-time college sports. Vice. https://sports.vice.com/en_us/article/ezexjp/four-years-a-student-athlete-the-racialinjustice-of-big-time-college-sports

Johnson, J. E., Wessel, R. D., \& Pierce, D. A. (2013). Exploring the influence of select demographic, academic, and athletic variables on the retention of student-athletes. Journal of College Student Retention: Research, Theory and Practice, 15(2), 135.

Ladson-Billings, G. (1995). But that's just good teaching! The case for culturally relevant pedagogy. Theory into Practice, 34(3), 159-165. http://www.jstor.org/stable/1476635

Ladson-Billings, G. (1998). Just what is critical race theory and what's it doing in a nice field like education? International Journal of Qualitative Studies in Education, 11(1), 7-24. https://doi.org/10.1080/095183998236863

Ladson-Billings, G. (2006). From the achievement gap to the education debt: Understanding achievement in U.S. schools. Educational Researcher, 35(7), 3-12. https://doi.org/10.2307/3876731 
Lavoie, C. (2014). Institutional racism and individual agency. Critical Social Work, 15(1). https://doi.org/10.22329/csw.v15i1.5906

Luzzo, D. A., Hasper, P., Albert, K. A., Bibby, M. A., \& Martinelli Jr, E. A. (1999). Effects of self-efficacy-enhancing interventions on the math/science self-efficacy and career interests, goals, and actions of career undecided college students. Journal of Counseling Psychology, 46(2), 233-243. https://doi.org/10.1037/0022-0167.46.2.233

Malcom-Piqueux, L. E., \& Mara Bensimon, E. (2015). Design principles for equity and excellence at Hispanic-serving institutions. Perspectivas: Issues in Higher Education Policy and Practice, 4, 1-16. https://vtechworks.lib.vt.edu/bitstream/handle/10919/83015/DesignPrinciplesforEquityan dExcellence.pdf?sequence $=1 \&$ is Allowed $=y$

Mark, S. L. (2016). Psychology of working narratives of STEM career exploration for nondominant youth. Journal of Science Education and Technology, 25(6), 976-993. https://doi.org/10.1007/s10956-016-9646-0

Mark, S. L., \& Alexander, O. (2019). A critical race case study exploration of two Black male student-athletes' STEM career development. Journal for the Study of Sports and Athletes in Education, 13(2), 116-145. https://doi.org/10.1080/19357397.2019.1633508

Martin, B., Harrison, C., \& Bukstein, S. (2010). "It takes a village" for African American male scholar-athletes. Journal for the Study of Sports and Athletes in Education, 4(3), 277-295. https://doi.org/10.1179/ssa.2010.4.3.277

Martin, W. C. (2008). The graduate transfer rule: Is the NCAA unnecessarily hindering studentathletes from traversing the educational paths they desire. Villanova Sports \& Entertainment Law Journal, 15(1), 103-134.

Murty, K. S., \& Roebuck, J. B. (2015). Deviant exploitation of Black male student athletes on White campuses. Deviant Behavior, 36(6), 429-440. https://doi.org/10.1080/01639625.2014.935691

National Science Board. (2016). Science and engineering indicators 2016 (NSB-2016-1). National Science Foundation. https://www.nsf.gov/statistics/2016/nsb20161/\#/report 
National Science Board. (2019). Science and engineering indicators: Degrees awarded to U.S. citizens and permanent residents, by degree level, sex, race, ethnicity, and field: 2000 and 2017. National Center for Education Statistics, Integrated Postsecondary Education Data System (IPEDS) Completions Survey, National Center for Science and Engineering Statistics, National Science Foundation, \& Integrated Data System (IDS). https://ncses.nsf.gov/pubs/nsb20197/demographic-attributes-of-s-e-degree-recipients

National Science Board. (2020). Science and engineering indicators 2020: The state of U.S. science and engineering (NSB-2020-1). National Science Foundation. https://ncses.nsf.gov/pubs/nsb20201/

NCAA. (2014). Accelerating academic success program current grant recipients with initiatives. https://www.ncaa.org/about/aasp-past-grant-recipients

NCAA. (2020). Where does the money go? http://www.ncaa.org/about/where-does-money-go

NCAA. (n.d.). How we support college athletes. http://www.ncaa.org/about/resources/mediacenter/ncaa-101/how-we-support-college-athletes

NCAA Research. (2016). Results from the 2015 GOALS study of the student-athlete experience. https://www.ncaa.org/about/resources/research/ncaa-goals-study

NCAA Research. (2018). Estimated probability of competing in professional athletics. https://www.ncaa.org/about/resources/research/estimated-probability-competingprofessional-athletics

President's Council of Advisors on Science and Technology (PCAST). (2010). Prepare and inspire: $K-12$ education in science, technology, engineering, and mathematics (STEM) for America's future. STEM Learning and Research Center. http://stelar.edc.org/publications/prepare-and-inspire-k-12-education-science-technologyengineering-and-math-stem

Roberts, D. (2013). Race, gender, and gender technologies: A new reproductive dystopia? In M. Wyer, M. Barbercheck, D. Cookmeyer, H. Ozturk, \& M. Wayne (Eds.), Women, science, and technology: A reader in feminist science studies (pp. 318 - 333). Routledge. 
Rubin, L. M. (2016). The detrimental effects of big-time college sports on Black studentathletes' academic success. Journal for the Study of Sports and Athletes in Education, 10(3), 185-198. https://doi.org/10.1080/19357397.2016.1258966

Sack, A. (2009). Clashing models of commercial sport in higher education: Implications for reform and scholarly research. Journal of Issues in Intercollegiate Athletics, 2, 76-92. http://citeseerx.ist.psu.edu/viewdoc/download?doi=10.1.1.473.6317\&rep=rep1\&type=pdf

Sailes, G. A. (1993). An investigation of campus stereotypes: The myth of Black athletic superiority and the dumb jock stereotype. Sociology of Sport Journal, 10(1), 88. https://doi.org/10.1123/ssj.10.1.88

Sellers, R. (2000). African American student-athletes: Opportunity or exploitation. In R. D. A. Brooks (Ed.), Racism in college athletics: The African American athlete's experience (2nd ed., pp. 133-154). Fitness Information Technology, Inc.

Small, T. (2016). Business ballers: Steph Curry, Lebron James, and 5 other NBA stars turned entrepreneurs. U.S. Chamber of Commerce. https://www.freeenterprise.com/basketballentrepreneurs/

Snyder, P. L. (1996). Comparative levels of expressed academic motivation among Anglo and African American university student-athletes. Journal of Black Studies, 26(6), 651-667. http://www.jstor.org/stable/2784859

Teel, D. (2019, May 24). ACC revenue up more than 10 percent for fourth time in five years. Daily Press. https://www.dailypress.com/sports/dp-spt-acc-revenue-taxes-0526story.html

Wilkes, E. C. (2014). Redshirting and academic performance: Evidence from NCAA studentathletes. [Master's thesis, Montana State University-Bozeman].

Wolverton, B. (2008). Rise in fancy academic centers for athletes raises questions of fairness. The Chronicle of Higher Education. https://www.chronicle.com/article/rise-in-fancyacademic-centers-for-athletes-raises-questions-of-fairness/ 